\title{
OPTIMIZATION OF ORDERS IN THE METAL INDUSTRY COMPANY
}

\author{
${ }^{1}$ Edyta KARDAS, ${ }^{2}$ Rafał PRUSAK \\ Czestochowa University of Technology, Czestochowa, Faculty of Production Engineering and Materials \\ Technology, Czestochowa, Poland, EU \\ 1ekonstan@wip.pcz.pl, 2prusak.rafal@wip.pcz.pl
}

https://doi.org/10.37904/metal.2019.986

\begin{abstract}
Every company, including metal industry company, forces every day with the problem of the quantity of ordered and stored materials used in production processes. The quantity depends mainly on the cost of their ordering and storage as well as technological requirements of the production process. The article presents the analysis of the optimal orders in the selected company of metal industry.
\end{abstract}

Keywords: Logistics, orders, optimization, metal industry

\section{INTRODUCTION}

One of the main problems of every production company is to ensure the continuity of production processes. It can be achieved by providing adequate resources, including material resources. The supply logistics is responsible for ensuring the right amount of materials for production processes. Its aim is to provide the quantity of materials so that the purchase and maintaining costs are optimal and that continuity of production process is achieved.

The main goal of the paper is the analysis the optimal orders in production company involved in the design and manufacture of metal constructions. Using the quantitative data from this company two analysis were carried out:

- $\quad \mathrm{ABC} / \mathrm{XYZ}$ analysis, that allowed to determine which materials are purchased the most often and which values were the highest,

- $\quad$ Analysis of the optimal order size and optimal order costs, which allowed to determine in what quantity, how often to buy individual materials and what are the total costs of that stocks.

\section{LOGISTICS OF SUPPLY}

Process of supply in the company is the important part of the logistics system, its main goal is to support the production and distribution system. Its correct operation has a major impact on the quality of product, the cost incurred in connection with the supply as well as the entire logistics system and the level of customer service quality [1-3].

Process of supply is the whole system solutions, that the aim of which is to satisfy all materials needs in the sphere of production, consumption or service. These relations are related to all activities related to effective determination of needs, price level negotiation, ordering, acceptance, transport, storage, maintenance, use, protection and control [4].

The main task of logistics of supply is to ensure that the company is effectively supplied with all materials that are important from the point of business. The point is to guarantee the quality, timeliness and completeness of materials supplies what determine the continuity of production process. Products in logistics of supply flow 
from suppliers operating on the market of raw materials to supply warehouses as a result of processes of logistics of supply [5].

The main tasks of logistics of supply are, among others [6]:

- The selection of the right suppliers,

- Maintaining relationships consistent with the adopted strategy of the company,

- Planning supply needs,

- $\quad$ Stock level control,

- Selection of the type of transport of goods and materials to the place of production process or sale.

All decisions regarding the ordering of goods or raw materials in the appropriate quantity should be based on planning supply needs. The planning process should be flexible, taking into account changes in demand, production schedule, disturbances affecting the supply process or behaviour of the supply market [7].

One of the important factors of logistics of supply is inventories of materials and products. The control of the level of inventories allows to react appropriately to their changes by placing an order for another batch of materials or reducing the level of stocks. The main problems of logistics of supply is to give answers to the following questions $[6,7]$ :

- What to buy? - buy or produce it yourself,

- Where to buy? - selection of suppliers,

- How much to buy? - determining the size of the batch,

- When to buy? - specification of the purchase date.

It should be also taken into account the cost of purchasing and maintaining the inventories to determine whether it is cheaper to order more frequently or store materials.

\section{CHARACTERISTICS OF THE COMPANY AND USED MATERIALS}

The research was carried out in the company dealing with the design and production of steel constructions. The company operates mainly in the Silesian Voivodship. In the production processes the company uses many different steel elements which are supplied to the company by three main large suppliers $[2,8]$ :

1) Konsorcjum Stali S.A. - consortium dealing with the distribution of steel, the production of construction reinforcements and steel construction. Currently, the company has 14 national departments in the whole Poland. The company's offer includes the following products: reinforcing steel, bars, cold rolled sections, hot rolled sections, pipes and sheets [9].

2) Bobrek - the main activity of the company is focused on providing high quality steel products. The offer includes mainly long produced manufactured in Polish steel plants, mainly: I-sections, channel sections, angle sections, rails, tee bars, closed profiles, bars, hot rolled sheets [10].

3) ArcelorMittal Poland - the company is the largest and at the same time the most modern steel producer in Poland. The company mainly produces: long products (e.g. hot-rolled sections, bars, wire), flat products (e.g. plates, sheets and strips) and special products (e.g. railway and tram rails, steel piles [11].

The analysis of values of supplies structure of the three largest suppliers was performed, the results of the analysis are presented in Figure 1. The presented results shows that the main supplier is Konsorcjum Stali S.A., as it realizes as much as $83 \%$ of all purchases, remaining companies execute a small percentage of orders: Bobrek - $11 \%$ and ArcellorMittal Poland $6 \%$. 


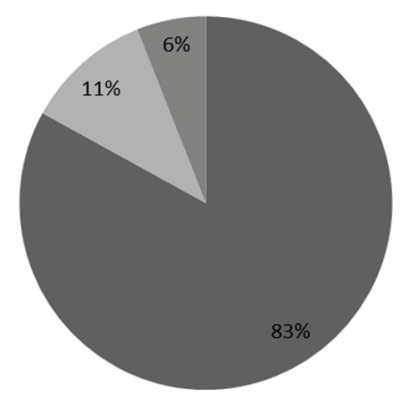

\section{Konsorcjum stali}

Bobrek

ArcelorMittal

Figure 1 The percentage of values of orders made by main suppliers of the company $[2,8,12]$

The analysis covers problem of supplies of main steel materials for the production process in the company. The analysis includes the following elements:
1) Sheets.
8) Angle sections.
2) Channel sections.
9) Slotted cages.
3) L-sections.
10) Reinforcing cages.
4) Reinforcing elements.
11) Flat bars.
5) Sheet piles.
12) Bars.
6) Sheet piles GU 7S.
13) Pipes.
7) Sheet piles GU-16-400.
14) Wire rods.

\section{4. $A B C / X Y Z$ ANALYSIS OF STOCKS}

The $A B C / X Y Z$ analysis of stocks held by the company under study was carried out. The analysed materials consist of 14 elements listed in a previous part of the paper. The analysis wad divided into two part:

- $\quad A B C$ - the analysis of products according to the value of orders,

- $\quad \mathrm{XYZ}$ - the analysis of products according to the number of orders.

Detailed results of this analysis were presented in work [2]. Final results of this analysis are presented in Table 1.

Table 1 Final results of the $A B C / X Y Z$ analysis of stocks $[2,8,12]$

\begin{tabular}{|c|c|c|c|c|}
\hline & \multicolumn{4}{|c|}{ Value of orders } \\
\hline \multirow{4}{*}{ 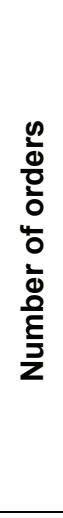 } & & A & B & C \\
\hline & $\mathbf{x}$ & Reinforcing elements & - & - \\
\hline & $\mathbf{Y}$ & - & $\begin{array}{c}\text { L-sections } \\
\text { Reinforcing elements } \\
\text { Sheet piles } \\
\text { Sheet piles GU-16-400 }\end{array}$ & $\begin{array}{c}\text { Sheets } \\
\text { Bars } \\
\text { Angle sections }\end{array}$ \\
\hline & $\mathbf{Z}$ & - & - & $\begin{array}{c}\text { Sheet piles } \\
\text { Flat bars } \\
\text { Channel sections } \\
\text { Slotted cages } \\
\text { Pipes } \\
\text { Wire rods }\end{array}$ \\
\hline
\end{tabular}


The results of the analysis (Table 1) showed that reinforcing elements (in group AX) are goods purchased the most often and at the highest demand. They are characterized by the highest value and regularity of purchase. In groups BY and CY there are goods that are bought quite often by the company, the value of their purchase is included in the average value of purchase made by the company. In the last group (CZ) there are goods bought occasionally and that purchase value is quite low.

\section{THE ANALYSIS OF OPTIMAL ORDER}

During the analysis of optimal order for materials, many factors should be taken into account: how many pieces of materials should be bought during one purchase, how much we can pay for ordering of product or how much we have to pay for maintaining of stocks. Calculation of values of these factors show the best solution. In order to the analysis of optimal order, the following indicators were used [13]:

1) The optimal order quantity $(Q)$ is the amount stocks that should be ordered by the company to ensure that its operation is not threatened and at the same time that accumulated stocks do not create unnecessary costs:

$Q=\sqrt{\frac{2 \cdot C_{d} \cdot R}{p \cdot i}}$

where:
$\mathrm{C}_{d}$ - unit costs of delivery
$\mathrm{R}$ - volume of demand
$\mathrm{i}$ - unit cost of maintaining of stocks
$\mathrm{p}$ - unit price of the material

2) Fix period of order per year $(T)$ is the appropriate date when the stocks should be checked and it there no stocks, re - order per year:

$T=\frac{Q}{R}$

3) Fix period of order per week ( $t$ ) is the appropriate date when the stocks should be checked and it there no stocks, re - order peer week:

$t=T \cdot 52$

4) The number of deliveries per year $(\mathrm{N})$ - how many times during the year the order should be made:

$N=\frac{R}{Q}$

5) The costs of purchase of materials $\left(C_{p}\right)$ - total cost of deliveries per year:

$C_{p}=N \cdot C_{d}$

6) The costs of maintaining of stocks $(\mathrm{Cm})$ - total cost of maintain of stocks in the company per year:

$C_{m}=\frac{i \cdot p \cdot Q}{2}$

7) The total cost of stocks $\left(\mathrm{C}_{\mathrm{t}}\right)$ - the sum of the cost of purchase and maintaining of stocks:

$C_{t}=C_{p}+C_{m}$

According to the formulas $(1-7)$ calculation of optimal order quantity and optimal cost of stocks was made. The results of analysis for each material was presented in Table 2. 
Table 2 Results of the analysis of optimal order quantity and optimal cost of stock [8, 12]

\begin{tabular}{|c|c|c|c|c|c|c|c|}
\hline Material & $\begin{array}{c}\text { Q - } \\
\text { optimal } \\
\text { order } \\
\text { quantity } \\
\text { (Mg) }\end{array}$ & $\begin{array}{c}\text { T - fixed } \\
\text { period of } \\
\text { order per } \\
\text { year }\end{array}$ & $\begin{array}{c}\text { t - fixed } \\
\text { period of } \\
\text { order per } \\
\text { week }\end{array}$ & $\begin{array}{c}\text { N - the } \\
\text { number } \\
\text { of } \\
\text { deliveries }\end{array}$ & $\begin{array}{c}\text { Cp - cost } \\
\text { of } \\
\text { purchase } \\
\text { of } \\
\text { material } \\
\text { (PLN) }\end{array}$ & $\begin{array}{c}\text { Cm - cost } \\
\text { of } \\
\text { maintaining } \\
\text { of stocks } \\
\text { (PLN) }\end{array}$ & $\begin{array}{c}\text { Ct - total } \\
\text { cost of } \\
\text { stocks } \\
\text { (PLN) }\end{array}$ \\
\hline Reinforcing elements & 255.69 & 0.015 & 0.77 & 67.12 & 892424 & 100679.2 & 993103.2 \\
\hline Reinforcing cages & 86.64 & 0.042 & 2.19 & 23.75 & 107016 & 35630.4 & 142646.4 \\
\hline L-sections & 68.67 & 0.043 & 2.25 & 23.15 & 82680 & 34730.6 & 117410.6 \\
\hline Sheet piles & 50.60 & 0.074 & 3.83 & 13.58 & 35724 & 20366.1 & 56090.1 \\
\hline Sheet piles GU-16-400 & 37.26 & 0.090 & 4.69 & 11.08 & 21476 & 16626.8 & 38102.8 \\
\hline Sheets & 42.73 & 0.079 & 4.10 & 12.69 & 28184 & 19028.7 & 47212.7 \\
\hline Slotted cages & 28.71 & 0.104 & 5.43 & 9.58 & 14300 & 14368.6 & 28668.6 \\
\hline Sheet piles GU 7S & 20.23 & 0.137 & 7.11 & 7.32 & 7696 & 10974.3 & 18670.3 \\
\hline Bars & 34.20 & 0.137 & 7.14 & 7.28 & 12948 & 10921.8 & 23869.8 \\
\hline Angle sections & 61.21 & 0.157 & 8.18 & 6.36 & 20228 & 9533.1 & 29761.1 \\
\hline Flat bars & 23.02 & 0.245 & 12.74 & 4.08 & 4888 & 6124.2 & 11012.2 \\
\hline Channel sections & 13.09 & 0.385 & 20.02 & 2.60 & 1768 & 3895.2 & 5663.2 \\
\hline Pipes & 4.41 & 0.441 & 22.95 & 2.27 & 520 & 3398.5 & 3918.5 \\
\hline Wire rods & 3.41 & 3.415 & 177.58 & 0.29 & 52 & 439.2 & 491.2 \\
\hline
\end{tabular}

According to the analysis of optimal order (Table 2) it can be concluded that:

- The order quantities presented in Table 2 are optimal values due to the costs. The ordering of smaller amount of materials increases the unit purchase costs, while the larger increases the cost of maintaining of stocks.

- $\quad$ In case of reinforcing elements the company should check the level of stocks at least once a week. 9 types of materials in warehouse should be controlled from every 2 to every 8 weeks, next three types of products should be inspected every several - dozen weeks. The last product was bought by the company only once, so the inspection of this type of material is not needed at all.

- The largest number of deliveries during a year concerns reinforcing elements, that are bought more frequently that once a week. Next groups of goods are those that number of deliveries varies between 24 and 10, while the least-bought products are those that number of deliveries does not exceed 10 during the year.

- As it resulted from obtained data, reinforcing elements are the most frequent and in the largest number, it is closely related to the profile of the activity of tested company. Next, reinforcing baskets are product that is bought very often, but in comparison to reinforcing elements they are bought in the amount of less than three times and three times less frequently than reinforcing elements. Products such as pipes and wire rods are purchased the least frequently, which is also given to the low cost in terms of purchase and maintaining. They are purchased only occasionally, in specific situation.

\section{CONCLUSION}

Supply logistics is an important element of company's logistic system. It plays very important role in the company's operation, it is also important factor affecting the success and maintenance of the company on the 
market. The basic task of supply logistics is to provide the products in the right quality and quantity, according to the order placed by the company and at the satisfactory costs.

The supply process should run smoothly and without any interference, because any delays or mistakes during supply process may result in delays in project implementation, financial penalties for delays, but also lack of trust from contractors and thus a wreaking position on the market.

The analysis presented in the paper was the first analysis carried out in this company. Results of research allowed to determine the size of optimal order in the terms of the number of ordered products, the frequency of their ordering, as well as the costs of orders and stocks. Using results, the company has opportunity to rationalize deliveries, improve the flow of goods between the warehouse and the destination, where products are manufactured.

The $A B C / X Y Z$ analysis showed clearly that reinforcing elements are products that is purchased the most frequently because of the highest demand on that material, they are bought regularly and their cost is the most significant. According to the analysis of optimal order it can be said that this product should be order at least once a week, because that schedule of order is optimal due to the total cost of stocks. It must be remembered that some materials are bought only occasionally. For example, pipe can be ordered every $4-5$ months and the percentage of this product in total cost of all stocks is negligible.

The analysis allowed to characterize the possibility of optimal orders of material in tested company in relation to its quantitative structure along with characteristics of costs of processes of ordering and maintaining of stocks. Thanks to this, the company can manage its capital better, can achieve even higher profits, has possibility to obtain further contract for realization of new projects. All these benefits come down to strengthening the company's position in the market.

\section{REFERENCES}

[1] HOLOTA, Tomas, HRUBEC, Jozef, KOTUS, Martin, HOLIENCINOVA, Maria, CAPOSOVA, Eva. The management of quality costs analysis model. Serbian Journal of Management. 2016. vol. 11, iss. 1, pp. 119-128. [viewed 2019-04-28]. Available from: doi:10.5937/sjm11-9347

[2] KARDAS, Edyta. The analysis of stock using ABC and XYZ methods in construction company. Logistics. 2013. Vol. 6, pp. 597-901.

[3] PUSTEJOVSKA, P., BROZOVA, S., INGALDI, M. The crucial logistics units in metallurgical production. In CLC 2013: Carpathian Logistics Congress, Ostrava: TANGER, 2017, pp. 572-576.

[4] WASYLKO, Mieczyslaw. Logistics in the national economy part II. Basic issue of micro logistics. Łódź: Scientific Publisher of University of Merchant, 2000.

[5] FICON, Krzysztof. Outline of micro logistics. Warsaw: BEL Studio, 2005.

[6] DEMBIŃSKA-CYRAN, Izabela, JEDLIŃSKI, Mariusz, MILEWSKA, Beata. Logistics. Selected topics for studying the subject. Szczecin: Szczecin University Publishing House, 2001.

[7] SARIUSZ WOLSKI, Zdzisław. Supply management strategy. Warsaw: PLACET Publishing Agency, 1998.

[8] OKONIEWSKA Agata. Supply logistics in the supply chain in the construction company. Master work under the direction of Edyta Kardas, Czestochowa University of Technology. Czestochowa 2013.

[9] www.konsorcjumstali.com.pl [viewed 2019-04-28].

[10] www.bobrek.pl [viewed 2019-04-28].

[11] www.poland.arcelormittal.com [viewed 2019-04-28].

[12] Information materials from Company.

[13] SULKA, M. Modelling of the optimal order size. Logistics. 2012. Vol. 6, pp. 589-593. 